Emir. J. Agric. Sci. 2005. 17 (2): 23-29

http://www.cfa.uaeu.ac.ae/Research/EJAS.htm

\title{
Trials of rabbitfish Siganus rivulatus production in floating cages in the Red Sea
}

\author{
Feisal A. Bukhari
}

Fisheries Research Center, Ministry of Agriculture, P.O. Box: 52681, Jeddah, 21573, Saudi Arabia

\begin{abstract}
Three trials were conducted on an important local fish species the Rabbitfish Siganus rivulatus in the Red Sea at the Fish Farming Center, Jeddah, Saudi Arabia. The first trial was to investigate the production of this species in three densities (80, 100 and $\left.120 / \mathrm{m}^{3}\right)$. In the second trial S. rivulatus was reared in two different sets of floating cage sizes (small of $10 \mathrm{~m}^{3}$ and large of $60 \mathrm{~m}^{3}$ ). The last trial was carried out to determine the suitable feeding rate $(7.5 \%$ and $15 \%$ of body weight) of a locally formulated feed. Results of the first trial showed no significant difference in the final weight and survival rates at the three stocking rates of S. rivulatus. Correlation analysis showed a negative influence of increasing stocking density on growth and survival. However, for the second and the third trials; a highly significant difference $(\mathrm{P}<0.05)$ was observed between feeding rates and cage sizes favoring the lower feeding rate of $7.5 \%$ and the smaller cages of $\left(10 \mathrm{~m}^{3}\right)$ respectively.
\end{abstract}

Key words: Fish, Rabbitfish Siganus rivulatus, Cage Culture, stocking densities, feed growth and production.

\section{Siganus rivulatus رلسلت عل إنتاجية ألسمك السيجلن (الصفي) في ألفه عائمة في البحر الأحمر فيطل عبد العزبز بخاري مركز لبحلث الثروة اللسمكية - وزارة الزراعة -صب. 52681جة 21573}

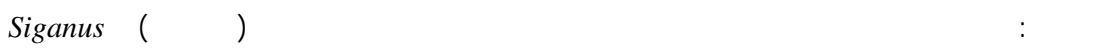
وكان rivulatus

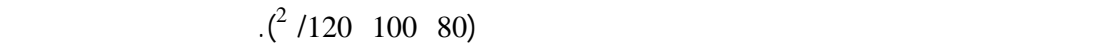

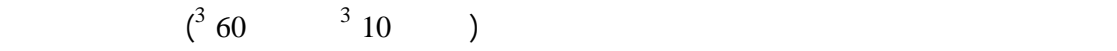

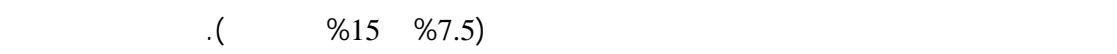

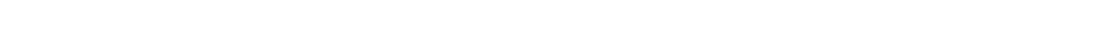

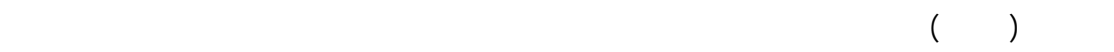

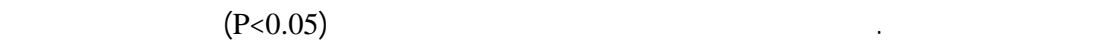

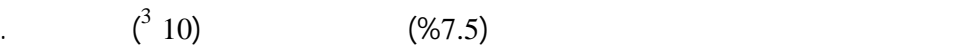
كمات مفتاحية: الأسمك، الأففاص العائمة، الكثافل، التغذية، النمو والإنتاج، لسٔسك للسجان. 


\section{Introduction}

Cages are water-based aquaculture facilities used for fish cultivation. Cages have enclosed bottoms as well as the sides by mesh or net screens. Cage culture originated two centuries ago and commercially valuable fish are cultured in cages throughout the world (Coche 1979 and Tacon et al., 1989). Cages differ in design, size, shape and location (floating or submersible), Although the majority consist of floating units (Beveridge 1996). Their floats and walkways are fabricated from wood and plastic barrels to polyethylene (HDPE), PVC or rubber pipe. The fish stock are kept in the cages using nets that are suspended frame with in the cage frame. The nets are made of flexible nylon or polyethylene. The size of cage and mesh depends on the age and species to be cultured. The mesh size of the net should be as large as possible to encourage good flow of water through the culture unit but be small enough not to allow the smaller individuals to escape. Typical dimensions range from 3 to $20 \mathrm{~m}$ in diameter and 3 to $10 \mathrm{~m}$ deep. Most commercial mariculture operations use nets of 250 to $1000 \mathrm{~m}^{3}$ in volume, corresponding to about 200 to $500 \mathrm{~m}^{2}$ of netting area. This is usually assembled in several panels, with suitable mounting rope, loops, and other fixings or attachments. As the nets must be handled regularly, and most cases frequently changed, they should be relatively light and manageable, yet durable. They should not cause damage to the stock, whether through trapping or abrasion. It is also common to use antifouling for net treatment such as organic copper, or organic tin compounds (Coche, 1979).

Floats are used to give buoyancy to the cages using plastic containers, PVC poles, Styrofoam, and air or foam filled plastic floats. Moorings are used to hold cages in position, particularly during rough seas and strong winds. The type and size of anchor used will depend on the nature of the sea bed and cage size. Shock absorbers (tires) are commonly used as protection between the various floating components, and are simply tied or chained onto cage frames, etc. Car tires are used approximately a double for every $1.5-2 \mathrm{~m}$ of joining frame length with particular taken at the corners of the cage. Plastic containers or scrap tires are used as additional shelter during heavy storms when connected to a chain and moored to absorb a considerable amount of wave energy.

Rabbitfish (Siganus spp.) are widely distributed in the Indo-Pacific region and have favorable aquaculture characteristics that make them a desirable culture species (Alban and Rosario 1962, Popper and Gunderman 1975, Herre \& Montalban 1928 and Robins, et al. 1991). Siganus rivulatus is one of several important species selected as part of the national mariculture development program in Saudi Arabia based on its good market value, in addition to augment fish protein supply in the Kingdom (Lichatowich et al., 1984a and 1984b). Recently the life cycle of $S$. rivulatus was completed and seed supply became available for culture without the need to collect juveniles from the Red Sea. (technical report of Fish Farming Center 2003). A commercial farm has already started production of $S$. rivulatus in Saudi Arabia.

A previous study conducted in the Red Sea on cage culture of S. rivulatus showed that the fish could reach harvest size $(100 \mathrm{~g})$ in 150 days if fish densities of up to $60 / \mathrm{m}^{3}$ (Lichatowich et al., 1984a). In the present study higher stocking densities, different cage sizes, and two feeding rates $(7.5 \%$ and $15 \%$ of body weight) were investigated for the cultivation of $S$. rivulatus in Saudi Arabia. 


\section{Materials and Methods}

Juveniles of $S$. rivulatus have been collected and brought to the Fish Farming Center from a shallow nursery ground north of Jeddah, using the collection method described by (Pillai 1962, Anon1979, Woodland, D. J. 1983 and Lichatowich et al., 1984a).

Three trials were conducted in flouting cages; distributed randomly in a northern Red Sea lagoon were Jeddah Fish Farming Center is situated. The lagoon average depth ranged between 6 -
$11 \mathrm{~m}$. of which the cages were located. All of the three trials lasted 180 days.

The first trial investigated three densities; using the densities 80, 100 and $120 / \mathrm{m}^{3}$ in small cages of $10 \mathrm{~m}^{3}$ $(2 \mathrm{~m} \times 2 \mathrm{~m} \times 2.5 \mathrm{~m})$ each. Fish feed was prepared daily containing soya meal, fish meal, maize, flour and vitamin-mineral premix (Table 1). All ingredients initially were minced and dry mixed. Water was added to form a cake and partially sun dried to allow the meal to harden in plastic feeding trays before suspending in the cages (Lichatowich et al., 1984b).

Table 1. Feed composition and proximate analysis of the test diets fed to Rabbit fish Siganus rivulatus in the three conducted trials in sea cages.

\begin{tabular}{lllc}
\hline \multicolumn{1}{c}{ Feed ingredients } & g kg-1 & \multicolumn{2}{c}{ Proximate analysis g kg-1 } \\
\hline Fish meal ${ }^{2}$ & 140 & Crude protein & 386 \\
Soya meal & 530 & Crude fat & 37.9 \\
Yellow corn (maze) & 150 & Crude fiber & 51.6 \\
Wheat flour & 150 & Total ash & 126.4 \\
Vitamin-mineral premix $^{3}$ & 30 & NFE4 & 449.7 \\
& & Energy5 (kJ g-1) & 183.7 \\
\hline
\end{tabular}

${ }_{1}$ control

${ }^{2}$ Peruvian fish meal, 65\% crude fat, from Nutrits Co., S.A., 3 Rue, Rosenwald, 75015 Paris, France.

${ }^{3}$ As reported by Jackson, Capper \& Matty (1982).

${ }^{4}$ Nitrogen-Free Extract, determined by difference.

${ }^{5}$ Gross energy, calculated based on 23.67, 17.17 and 39.79 kJ g-1 protein, carbohydrate and lipid, respectively.

The feeding rate used for the stocking density and cage size experiments was $15 \%$ of body weight per day. The ration was adjusted monthly considering the growth and survival.

The second trial incorporated feeding rates of $7.5 \%$ and $15 \%$ body weight per day. This trial was carried out also in small cages of $10 \mathrm{~m}^{3}$ $(2 \mathrm{~m} \times 2 \mathrm{~m} \times 2.5 \mathrm{~m})$ in three replicates.

The third trial was conducted to investigate cage size influence on growth and survival of $S$. rivulatus. For trial incorporated small cages of $10 \mathrm{~m}^{3}$ $(2 \mathrm{~m} \times 2 \mathrm{~m} \times 2.5 \mathrm{~m})$ each, and large cages of
$60 \mathrm{~m}^{3}(5 \mathrm{~m} \times 5 \mathrm{~m} \times 2.5 \mathrm{~m})$. Cage frames made of plywood and plastic containers were used as floating units. The treatments of all the trials were in triplicates and assigned randomly in the cage area. Ten percent of the stocks with an initial mean weight of $2.0 \mathrm{~g}$ were sampled monthly for growth using a field balance. Mortalities were counted and recorded daily. The smaller cages used for stocking density and feeding rate trial cages were anchored in $5 \mathrm{~m}$ water depths, and were brushed and cleaned to maximize better water circulation. Thus good water exchange depends on many factors mainly currents 
salinity and temperature (Beveridge, 1996).

Sea waters temperature ranged from 24.0 to $31.0^{\circ} \mathrm{C}$ and salinity from 38 to $40 \%$ and were within the acceptable tolerated levels (Westernhagen and Rosenthal 1975, and Kohno et al. 1988) respectively.

Samples were collected monthly for all trials by catching $5 \%$ of the fish population in each cage. Fish were crowded towards one side of the cage, scooped gently using a scoop net and placed in a known weight packet half filled with sea water. The weight of the sampled fish could be obtained by subtracting the packet's weight before and after. The average fish weight is recorded and the sampled fish was returned back to its corresponding cage.

Feed efficiency parameters

Feed efficiency parameters including fish weight gain (WG), feed conversion ratio (FCR), and protein efficiency ratio (PER) were calculated from the following equations:

1. $\mathrm{WG}=w 2-W 1$

Where $w_{2}=$ mean final weight (g) / fish, $w_{1}=$ mean initial weight (g) / fish.

2. FCR = feed (dry) intake (g) / wet weight gain $(\mathrm{g})$

3. PER $=W G / P$, where $P=$ protein intake.
Harvesting took place at the end of each experiment after the culture period of 180 days. From the weight measurements gathered, survival rates (\%) were computed and later analyzed statistically using ANOVA (Gomez and Gomez, 1984). Correlation analysis was also undertaken between stocking density and the parameters computed.

\section{Results}

Stocking density trial

In the stocking density trial, final weight of the Rabbitfish in three stocking rates did not differ significantly $(\mathrm{P}>0.05)$ (Table 2). However, correlation analysis showed that increasing stocking rate have a significant negative effect on weight increment $(\mathrm{r}=-0>99, \mathrm{P}<0.05)$. Survival rates did not differ significantly with most of the values exceeding more than $90 \%(\mathrm{P}<0.05)$. Again correlation analysis showed that higher stocking rates may effect survival negatively $(\mathrm{r}=-1.00$, $\mathrm{P}<0.01$ ). Production in all the densities was not significantly different yielding $10.20 \mathrm{~kg} / \mathrm{m}^{3}, 9.44 \mathrm{~kg} / \mathrm{m}^{3}$ and $8.13 \mathrm{~kg} / \mathrm{m}^{3}$ for the 80,100 and $120 / \mathrm{m}^{3}$ respectively (Table 2). No significant relationship was found between stocking density and production.

Table 2. Effect of stocking density on the production of the Rabbitfish S. rivulatus Values of growth and survival, production in sea cages; are shown below.

\begin{tabular}{cccccc}
\hline $\begin{array}{c}\text { Stocking } \\
\text { Density/m }\end{array}$ & $\begin{array}{c}\text { Mean initial wt. } \\
\text { (g fish -1 w1) }\end{array}$ & $\begin{array}{c}\text { Mean final wt. (g } \\
\text { fish -1 w2) }\end{array}$ & $\begin{array}{c}\text { Weight gain } \\
(\mathbf{g} \text { fish -1 w2-w1) }\end{array}$ & $\begin{array}{c}\text { Survival } \\
(\mathbf{\%})\end{array}$ & $\begin{array}{c}\text { Production } \\
\left(\mathbf{k g} / \mathbf{m}^{\mathbf{3}}\right)\end{array}$ \\
\hline 80 & 2.0 & $107.59 \mathrm{a}$ & $105.59 \mathrm{a}$ & $96.5 \mathrm{a}$ & $8.13 \mathrm{a}$ \\
100 & 2.0 & $100.95 \mathrm{a}$ & $98.95 \mathrm{a}$ & $95.6 \mathrm{a}$ & $9.44 \mathrm{a}$ \\
120 & 2.0 & $91.92 \mathrm{a}$ & $89.92 \mathrm{a}$ & $94.7 \mathrm{a}$ & $10.20 \mathrm{a}$ \\
\hline
\end{tabular}

Values in the same column with different superscripts are significantly different $(\mathrm{P}<0.05)$ (each value is a mean of three observations). 
Emir. J. Agric. Sci. 2005.17 (2): 23-29

http://www.cfa.uaeu.ac.ae/Research/EJAS.htm

Feeding rate trial

Results on the feeding rate trial revealed that final weight and production of $\mathrm{S}$. rivulatus in $7.5 \%$ ration was significantly higher $(\mathrm{P}<0.05)$ than that of $15 \%$ feed regime. Average final weight was $119.33 \mathrm{~g}$ in $15 \%$ feeding regime compared to $7.5 \%$ feeding regime that gave final weight of $80.97 \mathrm{~g}$. Production in $15 \%$ was $10.97 \mathrm{~kg} / \mathrm{m}^{3}$ unlike 7.55 $\mathrm{kg} / \mathrm{m}^{3}$ of $7.5 \%$ (Table 3). Survival rates of $94.7 \%$ in $15 \%$ ration and $96.42 \%$ in $7.5 \%$ ration were not significantly different $(\mathrm{P}<0.05)$ (Table 3).

Table 3. Effect of feeding rate on the production of the rabbitfish $S$. rivulatus in sea cages.

\begin{tabular}{|c|c|c|c|c|c|c|c|c|}
\hline $\begin{array}{c}\text { Feeding rate } \\
\text { (\% of body } \\
\text { weight) }\end{array}$ & $\begin{array}{l}\text { Mean initial } \\
\text { wt. (g fish -1 } \\
\quad \text { w1) }\end{array}$ & $\begin{array}{c}\text { Mean } \\
\text { final wt. } \\
\text { (g fish }-1 \\
w 2 \text { ) }\end{array}$ & $\begin{array}{l}\text { Weight } \\
\text { gain } \\
\text { (g fish -1 } \\
w 2-w 1 \text { ) }\end{array}$ & $\begin{array}{c}\text { Feed intake } \\
\text { (g fish -1) }\end{array}$ & FCR & PER & $\begin{array}{c}\text { Survival } \\
(\%)\end{array}$ & $\begin{array}{c}\text { Production } \\
\left(\mathrm{kg} \mathrm{m}^{3}-1\right)\end{array}$ \\
\hline $7.5 \%$ & 2.0 & 119.33 & 117.33a & 316.8 & $2.7: 1$ & $0.96 \mathrm{~b}$ & $94.7 a$ & 10.97a \\
\hline $15 \%$ & 2.0 & 80.97 & 78.97a & 284.3 & $3.6: 1$ & $0.72 a$ & $96.4 \mathrm{a}$ & $7.55 b$ \\
\hline
\end{tabular}

Figures with different superscripts are significantly different.

Cage size trial

As shown in Table 4, final weight, production and survival rates differed significantly in the two cage sizes $(\mathrm{P}<0.01)$. Higher average final weight of $119.33 \mathrm{~g}$ was obtained in the smaller cages $\left(10 \mathrm{~m}^{3}\right)$ compared to $84.03 \mathrm{~g}$ of that in large cages $\left(60 \mathrm{~m}^{3}\right)$. Survival was lower in the larger cages averaging $90.97 \%$ unlike that of the smaller cages averaging $94.69 \%$, meanwhile production of 10.97 and $6.80 \mathrm{~kg} / \mathrm{m}^{3}$ were obtained from the smaller and larger cages respectively.

Table 4. Effect of cage size on the production of the Rabbitfish $S$. rivulatus in sea cages.

\begin{tabular}{ccccc}
\hline Cage size & Initial weight (g) & Final weight (g) & Survival Rate (\%) & $\begin{array}{c}\text { Production } \\
\left(\mathbf{k g} / \mathbf{m}^{3}\right)\end{array}$ \\
\hline Small $\left(10 \mathrm{~m}^{3}\right)$ & 2.0 & 119.33 & $94.7 \mathrm{a}$ & $10.97 \mathrm{a}$ \\
Large $\left(60 \mathrm{~m}^{3}\right)$ & 2.0 & 84.03 & $91.0 \mathrm{a}$ & $6.80 \mathrm{~b}$ \\
\hline
\end{tabular}

Figures with different superscripts are significantly different.

\section{Discussion}

Previous studies on the growth of Rabbitfish in cages revealed slow growth in early juvenile phase but rapid in preadult phase (Tahil 1978a, Horstmann 1975 and Hashem 1983) which agrees with the findings of the present study. Even though there were variations in culture systems, species and diets in comparison to this study.

Unlike the initial study of Lichatowich et al., (1978b) using lower stocking rates that indicated achieving an average weight from 3.0-102.0 g in six months. The present study show that stocking rate can be increased up to $120 / \mathrm{m}^{3}$ and reaching the market size of $100 \mathrm{~g}$ in six months. Although the results revealed no significant difference in growth and survival between the tested densities $(\mathrm{P}>0.05)$ (Table 2), there is a tendency for lower growth and survival in $120 / \mathrm{m}^{3}$ density.

The survival rates of $S$. rivulatus in the present cage culture study were much higher compared to that of other studies of poorer survival rates resulted from rearing 
this particular species in tanks (Popper and Gunderman 1975).

Higher feeding rate was found to be suitable for the species while smaller cage was observed to be better. On the other hand, good water quality inside the smaller cage was due to better water exchange and lesser energy expenditure (Tacon et al., 1989). Less movement in a limited space may explain for the better production in the small cage. The study further highlights the mariculture potential of Rabbitfish Siganus rivulatus in cages along the Red Sea coast.

In conclusion, Rabbitfish Siganus rivulatus are slow growing fish. They should be fed no more than $7.5 \%$ of their live body weight. Furthermore, they grow better in smaller cages under the experimental conditions of the present study.

\section{References}

Ablan, G. L. and W. M Rosario. 1962. Method of collecting and transporting live teuthid fry (padas) for stocking. Philipp. Bur. Fish. Gas., 6:6-8,36.

Anon. 1979. The siganid mariculture. Quezon City, Min. Nat. Resources. 5p.

Ben-Tuvia, A., G. Kissil and D. Popper. 1973. Experiments in rearing Rabbitfish Siganus rivulatus in seawater. Aquaculture, 1:359-364.

Beveridge, M. C. M. 1996. Cage Culture. Second Edition. Fishing News Book, Oxford. 346 pp.

Coche, A. G. 1979. A review of cage fish culture and its application in Africa. In Advances Aquaculture, (Ed. By T.V.R. Pillay and W.A. Dill) pp. 42841. Fishing News Books, Oxford.

Gomez, K. A. and A. A. Gomez. 1984. Statistical Procedure for Agricultural
Research. Jone Wiley and sons, New York. 680 pp.

Hashem M. T. 1983. Biological studies on Siganus rivulatus (Forsskal) in the Red Sea. J. Fac. Mar. Sci., 3:119-128.

Herre, A. W. and H. Montalan. 1928. The Philippine siganids. Philipp.J. Sci., 35(2):151-185.

Horstmann. U. 1975. Some aspects of the mariculture of different siganid species in the Philippines. Philipp. Sci., 12:520.

Kohno, H., S. Hara, M. Duray and A. Gallego. 1988. Transition from endogenous to exogenous nutrition sources in larval Rabbitfish Siganus guttatus. Nippon Suisan Gakkaishi, 54 (7):1083-1091.

Lichatowich, T., S. Al-Thobaiti, M. Arada and F. Bukhari. 1984a. The spawning cycle, fry appearance and mass collection techniques for fry of Siganus rivulatus in the Red Sea. Aquaculture, 40:269-271.

Lichatowich, T., S. Al-Thobaiti, M. Arada and F. Bukhari. 1984b Growth of Siganus rivulatus reared in sea cages in the Red Sea. Aquaculture, 40:273-275.

Pillai, T. G. 1962. Siganid fish farming. In: Fish Farming Method in the Philippines, Indonesia and Hongkong. Rome, Fisheries Division, Biology Branch, Food and Agriculture Organization of the United Nations. P. 51-52. (Technical paper/FAO Fisheries Biology no.18).

Popper D. and N. Gunderman. 1975. Some ecological and behavioral aspects of siganid populations in the Red Sea and Mediterranean coast Israel in relation to their suitability for aquaculture. Aquaculture 6, 127-141. 
Tacon A. G. J., N. Rausin, M. Kadri, N. Runtuboy, B. Purwanto and Sunaryat. 1989. The food and feeding of Seabass, grouper and rabbitfish in floating net cages at the National Seafarming Development Center, Lampung Indonesia.

INS/81/008/Technical Paper/13. 130p.

Tahil A. S. 1978a. Experiments in rearing Siganus guttatus (Pisces: Osteichthyes, Siganidae) in a sea-cage and fishpens in the Philippines. Philipp.Sci., 15:50-66.
Westernhagen, H. M. and H. Rosenthal. 1975. Rearing and spawning siganids (Pisces: Teleostei) in a closed sea water system. Helgol. Wiss. Meeresunters, 27:1-18.

Woodland, D. J. 1983. Zoogeography of the Siganidae (Pisces): An interpretation of distribution and richness patterns. Bull. Mar. Sci., 33(3): 713-717. 